\title{
Changes in the invasion level, and impact of alien plants in Finnish semi-natural agricultural habitats
}

\author{
Miia Jauni ${ }^{1}$, Juha Helenius ${ }^{1}$ and Terho Hyvönen ${ }^{2}$ \\ ${ }^{1}$ Department of Agricultural Sciences, University of Helsinki, Latokartanonkaari 5, P.O. Box 27, FI-00014 University of \\ Helsinki, Finland, \\ ${ }^{2}$ MTT Agrifood Research Finland, Plant Production Research, Fl-31600 Jokioinen, Finland, \\ e-mail: miia.jauni@helsinki.fi
}

\begin{abstract}
Using dataset of 508 transects of $50 \mathrm{~m}^{2}$, we assessed changes in the invasion level of alien plant species in semi-natural agricultural habitats in three study years (2001, 2005 and 2010) in four geographical regions of Finland. In addition, the impact of environmental factors on the occurrence of the most common neophytes (alien species introduced after the $17^{\text {th }}$ century) and the impact of neophytes on native species diversity were studied. In total, 37 neophyte species were detected, but neophytes regarded as highly invasive were rare and occasional. We detected spatio-temporal variation in the invasion level, but it changed according to the measure used. For instance, alien species diversity was lower in south-western Finland than in other years in 2005, and the relative alien species richness was highest in southern and lowest in eastern Finland. Preferences for environmental conditions (disturbance, habitat type and geographical location) and the impact on plant diversity varied among the most common neophytes. The most common neophytes were positively rather than negatively associated with native and alien species diversity. The results suggest that alien species management and control methods should be species-specific and considered case-by-case. Neophytes do not yet cause severe problems, but regular monitoring is needed to detect changes in their invasion levels.
\end{abstract}

Key words: biological invasions, generalized linear mixed models, habitat type, neophyte, species diversity, temporal scale

\section{Introduction}

An alien plant is one whose presence in a region is due to intentional or accidental introduction as a result of human activity (Richardson et al. 2000). Due to adverse effects of alien plants on native species diversity and structure, functioning of ecosystems, human health and economic well-being, considerable attention has been paid to patterns and mechanisms of plant invasions and to the negative effects of alien species on resident communities (e.g. Levine et al. 2003, Rejmánek et al. 2005, Richardson and Pyšek 2006, Hejda et al. 2009, Simberloff 2011, Vilà et al. 2011). Invasion level refers to both the extent and severity of an alien plant invasion (e.g. Chytrý et al. 2008, Catford et al. 2012). In Europe, the invasion level of alien plants is considered to be lower in the boreal region than in central and southern Europe, but in highly disturbed habitats, such as agricultural habitats, the invasion level may be similar throughout the continent (e.g Chytrý et al. 2008, Chytrý et al. 2009, Pyšek et al. 2009, Jauni and Hyvönen 2010). Therefore, agricultural habitats should be the primary focus when considering alien plant invasions in the boreal region. 


\section{AGRICULTURAL AND FOOD SCIENCE}

M. Jauni et al. (2012) 21: 100-117

Among agricultural habitats, arable land is considered highly susceptible to invasions, whereas seminatural habitats, such as grasslands, are less frequently invaded by alien plant species (e.g. Chytrý et al. 2008, Pyšek et al. 2009). Generally, the susceptibility of different agricultural habitats to plant invasions is defined by environmental conditions, including geographical location, climate, the structure of the plant community, disturbance regime, resource availability and propagule pressure (e.g. Hobbs and Huenneke 1992, Lonsdale 1999, Rejmánek et al. 2005, Richardson and Pyšek 2006). In addition, plant invasions are characterized by spatio-temporal dynamics (e.g. Pyšek and Hulme 2005), which are often associated with a lag time with little or no increase in species occurrence, or geographical spread (e.g. Crooks 2005). The success of plant invasions varies according to species and is determined by the species traits and preferences for particular environmental conditions (e.g. Stohlgren et al. 1999, Richardson and Pyšek 2006). In addition, the effect of plant invasions on native species diversity and composition is largely species-specific, and the severity of the impact depends on the identity of the invading species (Hejda et al. 2009, Vilà et al. 2011). Thus, alien plant species cannot be viewed as a homogeneous group of species with similar responses to environmental conditions and similar impacts on the environment and biodiversity; speciesspecific research on alien plant species is needed (e.g. Stohlgren 1999, Hejda et al. 2009).

Although problems related to plant invasions have been noticed in Finland and a national strategy on invasive alien species has been made in order to reduce the impacts of invasive species on nature and socio-economic well-being (MMM 2012), studies of alien plant species in Finnish terrestrial habitats are scarce (but see e.g. Nummi 2001, Valtonen et al. 2006, Jauni and Hyvönen 2010, Hyvönen and Jalli 2011, Ranta and Viljanen 2011). In particular, the temporal and spatial variation in invasion level has generally been overlooked (but see Jauni and Hyvönen 2010, Hyvönen and Jalli 2011), although plant invasions are characterized by spatio-temporal dynamics and lag times (e.g. Crooks 2005, Pyšek and Hulme 2005). In addition, species-specific studies on alien species responses to environmental conditions and their effect on native species diversity are lacking. Only one previous Finnish study estimated the impact of alien plant species on plant species diversity and composition (Valtonen et al. 2006), despite measurement of the effect of alien plants on diversity and ecosystem functioning being important for nature conservation (e.g. Hejda et al. 2009, Simberloff 2011).

In this study we aimed at quantifying invasion level as (a) relative alien species richness (proportion of alien species in the total flora) and as (b) alien species diversity (measured using the Shannon-Wiener diversity index) in semi-natural agricultural habitats in Finland using comprehensive field data (e.g. Lonsdale 1999, Chytrý et al. 2008, Catford et al. 2012). We assessed recent change in invasion level over ten years in four different geographical regions, and determined the occurrence of neophyte plant species (alien introduced to Finland after early $17^{\text {th }}$ century). We expected invasion level and occurrence of neophytes to increase during the study years. We sought to determine the effect of environmental conditions on the most common neophytes in Finnish agricultural habitats, and to study the effect of neophyte invasion on native species diversity. We expected that the occurrence of the four most common neophyte species would decrease native species diversity, and that these species would have different responses to environmental conditions. In addition, we expected that the effect of the most common neophyte species on native species richness and diversity would vary according to neophyte species. 


\section{AGRICULTURAL AND FOOD SCIENCE}

M. Jauni et al. (2012) 21: 100-117

\section{Materials and methods}

\section{Study area and design}

The data originated from a long-term national monitoring study on the effects on species diversity of the Finnish agri-environmental scheme (see Kuussaari et al. 2008). A total of 52 sites $\left(1 \mathrm{~km}^{2}\right)$ in four geographic regions in Finland were selected using stratified random sampling (see details of the sampling design in Kuussaari et al. 2004, Jauni and Hyvönen 2010). The study regions were situated within the southern and central boreal vegetation zone, and included the three most important and intensively cultivated areas of Finland in the south, south-west and west, but also a less intensively cultivated area in eastern Finland.

In 2001, 2005 and 2010, vascular plants were recorded and their cover (\%) estimated (using a scale of nine classes: $1=<0.125 \%, 2=0.125-0.5 \%, 3=0.5-2 \%, 4=2-4 \%, 5=4-8 \%, 6=8-16 \%, 7=16-32 \%, 8=32-64 \%$, $9=>64 \%$ ) along 10-12 individual $50 \mathrm{~m}$ long and $1 \mathrm{~m}$ wide transect lines at each $1 \mathrm{~km}^{2}$ site (see details in Kuussaari et al. 2008, Jauni and Hyvönen 2010). All transects were located in non-crop habitats representing five distinct habitat types: (1) field margin, (2) forest margin, (3) road margin, (4) grassland, and (5) other habitats (details Jauni and Hyvönen 2010). In addition to the habitat type, environmental variables included data on geographical location, habitat quality and disturbance. Spatial variables, longitude and latitude, were defined from the mid-point of each transect line. The variables for describing the quality and disturbance regime of the habitats included: (1) shadiness (four classes based on exposure to sunshine: sun-baked, sunny and open, partly shady, shady), (2) moisture (three classes: dry, mesic, moist), (3) mowing (mown, not mown), and (4) the proportion of bare ground (estimated in 9-step \%-classes). In addition, native and alien species richness as the numbers of native and alien (including neophytes and archaeophytes) plant species along each transect were included as environmental variables. In this study, we included data only on those 508 transects that remained the same in all study years.

The plant species nomenclature follows that of Hämet-Ahti et al. (1998). The species were categorized as native, archaeophyte or neophyte according to Hämet-Ahti et al. (1998) and Suominen and Hämet-Ahti (1993). Neophytes were introduced into Finland after the early $17^{\text {th }}$ century and archaeophytes before that date (Hämet-Ahti et al. 1998). The information on the invasive neophytes was derived from the North European and Baltic Network on Invasive Alien Species (NOBANIS 2011) and Finland's National Strategy on Invasive Alien Species (MMM 2012). In addition, potentially invasive species, which could threaten native biological diversity, were regarded as being invasive. NOBANIS (2011) follows the definition of The Convention on Biological Diversity, i.e. an invasive alien species is a species whose introduction and/or spread threatens biological diversity and is applied to northern Europe, whereas the definition in the Finland's National Strategy on Invasive Alien Species (MMM 2012) encompasses also economic, health and social hazards, and is applied only to Finland. Both of these definitions differ from the definition suggested by Richardson et al. (2000), who used reproduction and potential of spread over long distances as criteria for classification as invasive, and excluded any indication of impact.

\section{Data analyses}

The frequencies of occurrence of neophytes, which indicate the proportion (\%) of $50 \mathrm{~m}^{2}$ transect lines in which the species was found of the total number of transects, were calculated for each study year. The level of invasion was expressed as (a) relative alien species richness (measured as proportion of alien species (including neophytes and archaeophytes) in the total flora) and (b) alien species diversity (measured as Shannon-Wiener diversity index calculated by using \% cover estimates) for three study years and for 


\section{AGRICULTURAL AND FOOD SCIENCE}

M. Jauni et al. (2012) 21: 100-117

four geographical regions. The relative alien species richness indicate the contribution that alien species make to a community, and it is easy to measure, can be applied to various taxa, independent of scale and comparable across regions and ecosystems (Catford et al. 2012), especially when sample sizes are not equal. Thus the relative alien species richness is recommended as a measure of invasion level and we have used it in our previous study, as well (Jauni and Hyvönen, 2010; Catford et al. 2012). Since we did not have equal sample size for the different geographic regions, the use of relative measures was needed. We used Shannon-Wiener diversity index because it provides information of the relative dominance of species, and account also for species' evenness, thus being more informative than richness and abundance used separately (e.g. Catford et al. 2012). The difference in the level of invasion between the study years, the difference between geographical regions and the differences between the study years within the regions were tested with one-way ANOVA. We performed multiple tests on the same data, which would have inflated the probability of type I errors. To avoid this problem, we used the sequential Bonferroni correction (e.g. Holm 1979).

The analyses on the effect of environmental variables on the neophytes, and on the impact of neophytes on plant diversity were conducted with the four most common neophytes in semi-natural agricultural habitats: Achillea ptarmica L., Epilobium adenocaulon Hausskn., Galium album Mill. and Trifolium hybridum L. According to the latest evaluation of invasive alien species, E. adenocaulon and G. album are regarded as invasive neophytes in Finland, whereas A. ptarmica and T. hybridum are not invasive, i.e. they do not threaten the biological diversity or cause economic or health hazards (MMM 2012). All of these four neophytes are perennials. A. ptarmica (first observation in Finland in 1673), G. album (first observation in 1802) and T. hybridum (first observation in 1877) originate from Europe or Eurasia and were introduced through agriculture, whereas $E$. adenocaulon was introduced through horticulture and transportation from North America in 1910 (Suominen \& Hämet-Ahti 1993, Hämet-Ahti et al. 1998, Lampinen and Lahti 2011).

We used Pearson's chi-square test to compare the frequency of A. ptarmica, E. adenocaulon, G. album and T. hybridum between invaded and uninvaded transects in different habitat types. The differences in native species richness, and native diversity (measured as Shannon-Wiener diversity index of native species) between invaded and uninvaded transects, were estimated with a t-test or a Kruskal-Wallis test in case the equality of the variances not being attained. These differences were used to measure the effect of invasion on the community characteristics (see e.g. Hejda et al. 2009). We tested the effect of environmental variables on A. ptarmica, E. adenocaulon, G. album and T. hybridum. First, principal components analyses (PCA) were conducted separately to each study year using correlation matrix and Varimax rotation to summarise the environmental data, and to reduce the multicollinearity among the five environmental variables: shadiness, moisture, the proportion of bare ground, alien and native species richness (e.g. Kent and Coker 1992). The missing values were excluded list-wise. The categorical variables, habitat type and mowing, were excluded from the PCA. Non-normally distributed variables were log-transformed if the transformation improved normality. PCA was performed with PASW Statistics 17 (SPSS Inc. 2009). Then, we used generalized linear mixed models (GLMM) with a binomial distribution. The presence-absence data for each species (A. ptarmica, E. adenocaulon, G. album and T. hybridum) was used as the response variable and habitat type, mowing and the principal components of the environmental variables with eigenvalues higher than one were included as explanatory variables in the analyses (see Table 3 for the PCA components used as explanatory variables). To overcome problems of spatial dependence of the study sites, the ID number of each $1 \mathrm{~km}^{2}$ site was used as a random term. All models were built using backward deletion of non-significant explanatory variables starting with the full model (AIC, z-test, $p=0.05$ ). The models were analysed with Ime4 package in R 2.10.0 (R Development Core Team 2011, Bates et al. 2011). 


\section{AGRICULTURAL AND FOOD SCIENCE}

M. Jauni et al. (2012) 21: 100-117

\section{Results \\ The change in the invasion level between sampling times}

In total, 303 vascular plant species were recorded in 2001, 291 in 2005, and 308 in 2005, of which 103 (34.0\%), 100 (34.4\%) and 109 (35.4\%) were alien species (including archaeophytes and neophytes), respectively. Of the alien species, 18 (17.5\%) were neophytes in 2001, $22(22.0 \%)$ in 2005, and $26(23.9 \%)$ in 2010. We measured the invasion level as relative alien species richness i.e. proportion of alien species (including archaeophytes and neophytes) of the total flora, and alien species diversity (Shannon-Wiener diversity index). We did not detect differences in relative alien species richness between study years. On average, alien species diversity was lower in 2005 than in 2010 ( $t=-3.53, p<0.001)$ or 2001 ( $t=4.73, p<0.001)$ (Fig. 1). We did not found significant difference between the years 2001 and 2010 regarding the diversity of alien plant species ( $t=1.23, p>0.05)$.
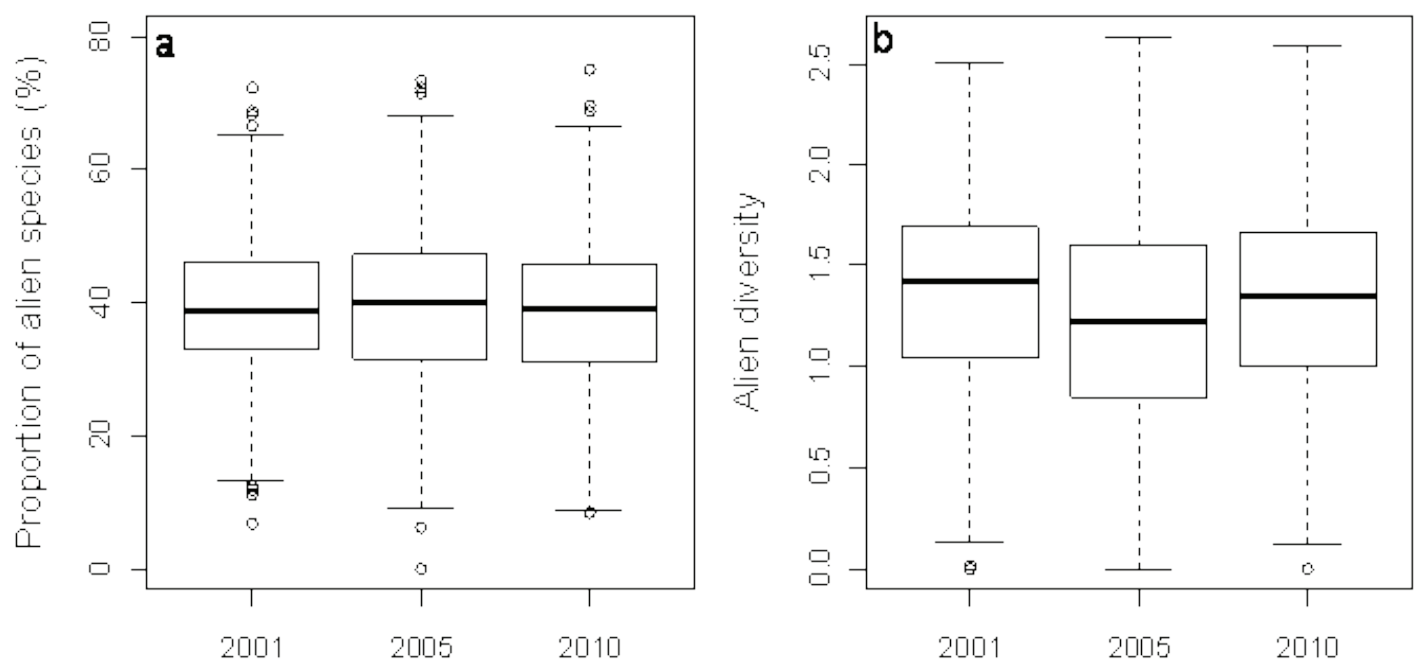

Figure 1. The invasion level as (a) a proportion of alien species (including archaeophytes and neophytes) of the total flora and (b) Shannon-Wiener diversity index of alien species in $50 \mathrm{~m}^{2}$ transect $(\mathrm{N}=508)$ lines in semi-natural agricultural habitats in 2001, 2005 and 2010.

The relative alien species richness and alien diversity (Shannon-Wiener diversity index) differed among geographical regions $(\mathrm{F}=12.46, p<0.001)$ (Fig. 2). For each study year, the relative alien species richness was highest in southern and lowest in eastern Finland. In 2010, alien diversity (Shannon-Wiener diversity index) was highest in eastern Finland and lowest in southern Finland, whereas in 2001 the opposite was apparent. In 2005, alien species diversity was markedly lower in south-western Finland than in the other study regions. We did not found difference in the relative alien species richness within geographical regions between the study years $(\mathrm{F}=0.43, p=0.652)$. In western Finland, alien species diversity was significantly lower in 2005 than in 2001 and 2010 ( $F=29.72, p<0.001$ ) (Fig 2). In southern Finland alien species diversity decreased during the three study year ( $F=5.45, p=0.027)$, whereas in eastern Finland it increased ( $F=5.64$, $p=0.028)$. No significant differences in alien species diversity were established between the three study years in western Finland ( $\mathrm{F}=0.71, p=0.988)$. 


\section{AGRICULTURAL AND FOOD SCIENCE}

M. Jauni et al. (2012) 21: 100-117
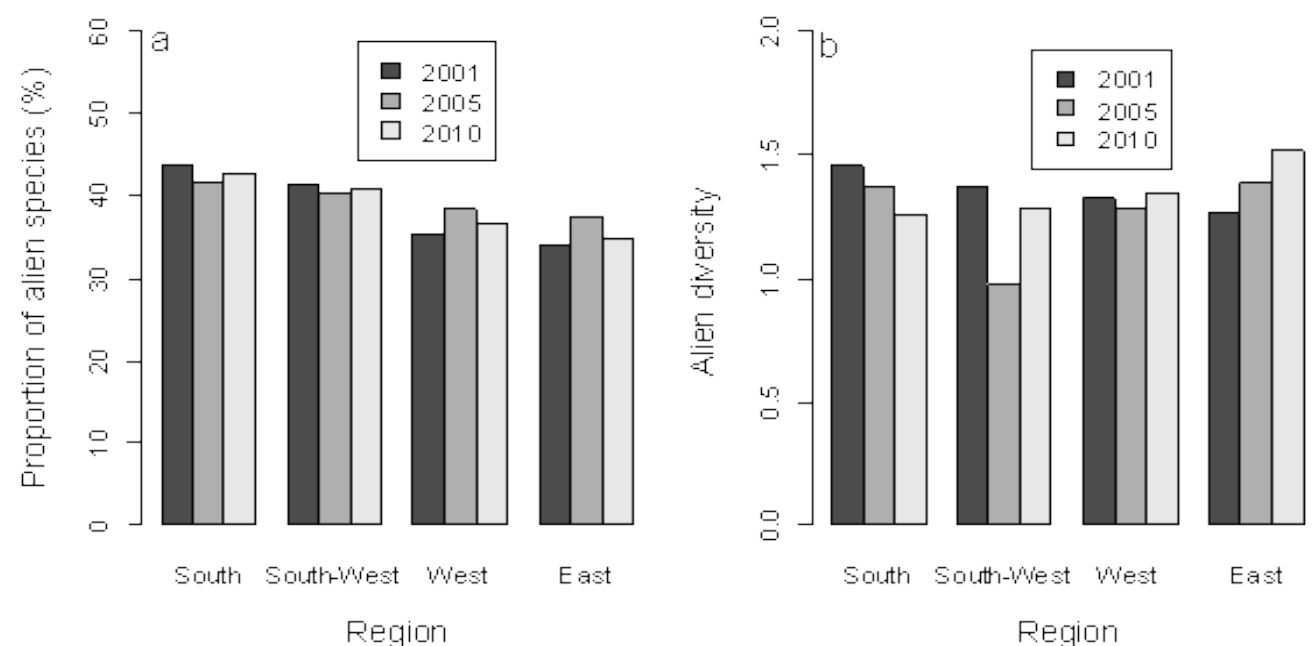

Figure 2. The invasion level as mean (a) a proportion of alien plant species (including archaeophytes and neophytes) of the total flora and (b) Shannon-Wiener diversity index of alien species in $50 \mathrm{~m}^{2}$ transect lines (N=508) in semi-natural agricultural habitats in four different regions (southern, south-western, western and eastern Finland) in three study years: 2001, 2005 and 2010.

\section{Occurrence and effects of neophytes}

In total, 37 neophytes were recorded from all $50 \mathrm{~m}^{2}$ transect lines in the three study years (Table 1). According to NOBANIS (2011), 27 of those species (73.0\%) were invasive, whereas according to the Finland's National Strategy on Invasive Alien Species (MMM 2012) 9 (24.3\%) were invasive neophytes. In 2001, $83.3 \%$ of the neophytes were invasive, in $200581.8 \%$ and in $201073.1 \%$ according to NOBANIS (2011), and according to the National Strategy for Invasive Alien Species, 27.8\%, 27.3\% and 23.1\%, respectively. Most of the invasive neophytes, defined by the National Strategy for Invasive Alien Species, (Amelanchier spicata (Lam.) K., Calystegia sepium (L.) R.Br., Epilobium ciliatum Raf., Galium x pomeranicum Retz., Sambucus racemosa L., Symphytum officinale L.), were rare (i.e. occurred $<5$ transects) and occasional (i.e. did not occur every year), except for E. adenocaulon and G. album. Lupinus polyphyllus Lindl. occurred only in three of the $50 \mathrm{~m}^{2}$ transect lines every year.

The frequency of occurrence of $E$. adenocaulon increased each year from $14.8 \%$ in 2001 to $21.1 \%$ in 2010 (Table 1). The frequency of occurrence of T. hybridum decreased from $25.8 \%$ in 2001 to $17.1 \%$ in 2005 and $17.3 \% 2010$, whereas the frequencies of occurrence of $A$. ptarmica and G. album were lowest in 2005. Every study year, road margins were overrepresented as a habitat type in transects occupied by A. ptarmica and $T$. hybridum compared with transects, from where these species were absent, whereas $G$. album and $E$. adenocaulon were equally represented in all habitat types (Appendix 1). In each study year, native species richness and diversity (measured as Shannon-Wiener diversity index) were higher in transects invaded by $A$. ptarmica than in transects from where it was absent (Tables 2, 3 and 4). In 2001 and 2005, in transects where E. adenocaulon occurred, native species richness and diversity were higher than in transects uninvaded by E. adenocaulon. In 2010, invaded transects did not differ from uninvaded transects. In 2001, native species richness was lower in transects where G. album or T. hybridum did not occur, than in invaded transects. In addition, the native species diversity was lower in transects unoccupied by $T$. hybridum than in transects occupied by T. hybridum in 2001. In 2005 and 2010, transects invaded by G. album or T. hybridum did not differ from uninvaded transects in terms of native species richness and diversity. 


\section{AGRICULTURAL AND FOOD SCIENCE}

M. Jauni et al. (2012) 21: 100-117

Table 1. Frequency of occurrence of neophytes (proportion of the $50 \mathrm{~m}^{2}$ transect lines (\%) in which neophyte species were found, $\mathrm{N}=508$ ) in semi-natural agricultural habitats in Finland in 2001, 2005 and 2010.

\begin{tabular}{|c|c|c|c|c|c|c|}
\hline \multirow[t]{2}{*}{ Species } & \multicolumn{2}{|c|}{ Frequency $(\%)$} & \multicolumn{2}{|r|}{ Change } & \multirow[b]{2}{*}{$2010-2001$} & \multirow[b]{2}{*}{ 2010-2005 } \\
\hline & 2001 & 2005 & 2010 & $2005-2001$ & & \\
\hline Achillea ptarmica L. $^{1}$ & 49.6 & 42.9 & 51.8 & -6.7 & 2.2 & 8.9 \\
\hline Amelanchier spicata (Lam.) K., & 0.0 & 0.2 & 0.0 & 0.2 & 0.0 & -0.2 \\
\hline Anethum graveolens $\mathrm{L}$. & 0.0 & 0.0 & 0.2 & 0.0 & 0.2 & 0.2 \\
\hline Anthemis tinctoria $\mathrm{L}$. & 0.0 & 0.2 & 0.2 & 0.2 & 0.2 & 0.0 \\
\hline Artemisia absinthium $\mathrm{L}$. & 0.0 & 0.2 & 0.0 & 0.2 & 0.0 & -0.2 \\
\hline Barbarea vulgaris $\mathrm{R} . \mathrm{Br} .^{1}$ & 4.9 & 3.0 & 4.7 & -2.0 & -0.2 & 1.8 \\
\hline Brassica napus ssp. oleifera (Moench) Metzg. & 0.0 & 0.8 & 0.2 & 0.8 & 0.2 & 0.6 \\
\hline Bromus inermis Leyss. ${ }^{1}$ & 0.0 & 0.2 & 0.0 & 0.2 & 0.0 & -0.2 \\
\hline Bunias orientalis $\mathrm{L}^{1}$ & 0.0 & 0.0 & 0.4 & 0.0 & 0.4 & 0.4 \\
\hline Calystegia sepium (L.) R.Br. ${ }^{1,2}$ & 0.0 & 0.0 & 0.2 & 0.0 & 0.2 & 0.2 \\
\hline Cerastium arvense L. ${ }^{1}$ & 1.4 & 3.3 & 0.8 & 2.0 & -0.6 & -2.6 \\
\hline Cerastium glomeratum Thuill. ${ }^{1}$ & 0.0 & 0.0 & 0.4 & 0.0 & 0.4 & 0.4 \\
\hline Chaerophyllum prescottii DC. & 4.3 & 0.0 & 0.0 & -4.3 & -4.3 & 0.0 \\
\hline Convolvulus arvensis $\mathrm{L}$. & 0.0 & 0.0 & 0.2 & 0.0 & 0.2 & 0.2 \\
\hline Crataegus grayana Eggl. ${ }^{1}$ & 0.4 & 0.0 & 0.0 & -0.4 & -0.4 & 0.0 \\
\hline Daucus carota $\mathrm{L}$. & 0.0 & 0.0 & 0.8 & 0.0 & 0.0 & 0.8 \\
\hline Epilobium adenocaulon Hausskn. ${ }^{1,2}$ & 14.8 & 17.1 & 21.1 & 2.4 & 6.3 & 3.9 \\
\hline Epilobium ciliatum Raf. $^{1,2}$ & $0 . .0$ & 0.2 & 0.2 & 0.2 & 0.2 & 0.0 \\
\hline Festuca trachyphylla (Hack.) Krajina ${ }^{1}$ & $0 . .0$ & 0.0 & 5.7 & 0.0 & 5.7 & 5.7 \\
\hline Galium album Mill. ${ }^{1,2}$ & 23.4 & 19.1 & 22.8 & -4.3 & -0.6 & 3.7 \\
\hline Galium x pomeranicum Retz..$^{1,2}$ & 0.2 & 0.8 & 0.0 & 0.6 & -0.2 & -0.8 \\
\hline Heracleum spondylium L. ${ }^{1}$ & 0.0 & 0.0 & 1.8 & 0.0 & 1.8 & 1.8 \\
\hline Lolium multiflorum Lam. ${ }^{1}$ & 0.2 & 0.8 & 0.2 & 0.6 & 0.0 & -0.6 \\
\hline Lolium perenne $\mathrm{L}^{1}{ }^{1}$ & 3.3 & 1.4 & 1.6 & -2.0 & -1.8 & 0.2 \\
\hline Lupinus polyphyllus Lindl. ${ }^{1,2}$ & 0.6 &. .6 & 0.6 & 0.0 & 0.0 & 0.0 \\
\hline Luzula luzuloides (Lam.) Dandy \& Wilmott ${ }^{1}$ & 0.0 & 0.2 & 0.0 & 0.2 & 0.0 & -0.2 \\
\hline Matricaria matricarioides (Less.) Porter ${ }^{1}$ & 5.7 & 6.3 & 7.9 & 0.6 & 2.2 & 1.6 \\
\hline Medicago lupulina $\mathrm{L}^{1}{ }^{1}$ & 0.0 & 0.0 & 0.2 & 0.0 & 0.2 & 0.2 \\
\hline Potentilla thuringiaca Bernh. ex Link & 0.2 & 0.0 & 0.0 & -0.2 & -0.2 & 0.0 \\
\hline Ribes uva-crispa L. $^{1}$ & 0.2 & 0.2 & 0.0 & 0.0 & -0.2 & -0.2 \\
\hline Salix fragilis $\mathrm{L} .{ }^{1}$ & 0.0 & $0 . .2$ & $0 . .0$ & 0.2 & 0.0 & -0.2 \\
\hline Sambucus racemosa $\mathrm{L}^{12}$ & 0.2 & 0.0 & 0.0 & -0.2 & -0.2 & 0.0 \\
\hline Senecio viscosus $\mathrm{L}^{1}$ & 0.2 & 0.2 & 1.6 & 0.0 & 1.4 & 1.4 \\
\hline Symphytum officinale L. ${ }^{1,2}$ & 0.0 & 0.0 & 0.2 & 0.0 & 0.2 & 0.2 \\
\hline Thlaspi caerulescens J. Presl \& C. Presl & 1.4 & 1.6 & 0.2 & 0.2 & -1.2 & -1.4 \\
\hline Trifolium hybridum L. ${ }^{1}$ & 25.8 & 17.1 & 17.3 & -8.7 & -8.5 & 0.2 \\
\hline Vicia sativa $\mathrm{L}$. & 0.0 & 0.0 & 0.2 & 0.0 & 0.2 & 0.2 \\
\hline Total species number & 18 & 22 & 26 & & & \\
\hline
\end{tabular}

${ }^{1}$ Invasive according to North European and Baltic Network on Invasive Alien Species (NOBANIS 2011)

${ }^{2}$ Invasive according to Proposal for a National Strategy on Invasive Alien Species (MMM 2012) 


\section{AGRICULTURAL AND FOOD SCIENCE}

M. Jauni et al. (2012) 21: 100-117

Table 2. Mean ( \pm SD) species richness and Shannon-Wiener diversity index of native species in 2001 for $50 \mathrm{~m}^{2}$ transect lines $(\mathrm{N}=508)$ where a neophyte (Achillea ptarmica, Epilobium adenocaulon, Galium album or Trifolium hybridum) is present or absent. The difference between transects, in which a neophyte is present (Invaded) or absent (Uninvaded), was tested with t-test or with Kruskal-Wallis test, if variances where not equal ( $p$-value $* * *<0.001, * *<0.01, *<0.05$, NS $=$ nonsignificant).

\begin{tabular}{llll}
\hline Diversity variable & Invaded & Uninvaded & Difference \\
\hline Achillea ptarmica & & & \\
Richness & $18.64 \pm 7.82$ & $14.11 \pm 6.21$ & $-4.53 * * *$ \\
Diversity & $1.87 \pm 0.46$ & $1.66 \pm 0.47$ & $-0.21 * * *$ \\
Epilobium adenocaulon & & & \\
Richness & $20.73 \pm 8.74$ & $15.60 \pm 6.89$ & $-5.13 * * *$ \\
Diversity & $1.94 \pm 0.43$ & $1.73 \pm 0.48$ & $-0.21 * * *$ \\
Galium album & & & \\
Richness & $19.48 \pm 7.56$ & $15.41 \pm 7.10$ & $-4.07 * * *$ \\
Diversity & $1.78 \pm 0.47$ & $1.74 \pm 0.51$ & $-0.04 \mathrm{NS}$ \\
Trifolium hybridum & & & \\
Richness & $19.44 \pm 7.85$ & $15.29 \pm 6.94$ & $-4.15 * * *$ \\
Diversity & $1.85 \pm 0.45$ & $1.74 \pm 0.48$ & $-0.11 *$ \\
\hline
\end{tabular}

Table 3. Mean ( \pm SD) species richness and Shannon-Wiener diversity index of native species in $2005 \mathrm{for}^{2} \mathrm{~m}^{2}$ transect lines $(\mathrm{N}=508)$ where a neophyte (Achillea ptarmica, Epilobium adenocaulon, Galium album or Trifolium hybridum) is present or absent. The difference between transects, in which a neophyte is present (Invaded) or absent (Uninvaded), was tested with t-test or with Kruskal-Wallis test, if variances where not equal ( $p$-value $* * *<0.001, * *<0.01, *<0.05$, NS $=$ nonsignificant).

\begin{tabular}{llll}
\hline Diversity variable & Invaded & Uninvaded & Difference \\
\hline Achillea ptarmica & & & \\
Richness & $16.86 \pm 6.48$ & $12.73 \pm 8.27$ & $-4.13 * * *$ \\
Diversity & $1.73 \pm 0.53$ & $1.48 \pm 0.56$ & $-0.25 * * *$ \\
Epilobium adenocaulon & & & \\
Richness & $16.94 \pm 6.45$ & $14.00 \pm 6.25$ & $-2.94 *$ \\
Diversity & $1.79 \pm 0.52$ & $1.54 \pm 0.56$ & $-0.25 * * *$ \\
Galium album & & & \\
Richness & $15.70 \pm 6.58$ & $14.22 \pm 6.30$ & $-1.48 \mathrm{NS}$ \\
Diversity & $1.64 \pm 0.60$ & $1.57 \pm 0.55$ & $-0.07 \mathrm{NS}$ \\
Trifolium hybridum & & & \\
Richness & $14.95 \pm 6.16$ & $14.41 \pm 6.42$ & $-0.54 \mathrm{NS}$ \\
Diversity & $1.66 \pm 0.52$ & $1.57 \pm 0.57$ & $-0.09 \mathrm{NS}$ \\
\hline
\end{tabular}




\section{AGRICULTURAL AND FOOD SCIENCE}

M. Jauni et al. (2012) 21: 100-117

Table 4. Mean ( \pm SD) species richness and Shannon-Wiener diversity index of native species in 2010 for $50 \mathrm{~m}^{2}$ transect lines $(\mathrm{N}=508)$ where a neophyte (Achillea ptarmica, Epilobium adenocaulon, Galium album or Trifolium hybridum) is present or absent. The difference between transects, in which a neophyte is present (Invaded) or absent (Uninvaded), was tested with t-test or with Kruskal-Wallis test, if variances where not equal ( $p$-value $* * *<0.001, * *<0.01, *<0.05$, NS=nonsignificant).

\begin{tabular}{llll}
\hline Diversity variable & Invaded & Uninvaded & Difference \\
\hline Achillea ptarmica & & & \\
Richness & $18.67 \pm 6.00$ & $14.00 \pm 5.44$ & $-4.67 * * *$ \\
Diversity & $1.99 \pm 0.41$ & $1.71 \pm 0.49$ & $-0.28 * * *$ \\
Epilobium adenocaulon & & & \\
Richness & $16.15 \pm 6.15$ & $16.49 \pm 6.21$ & $0.34 \mathrm{NS}$ \\
Diversity & $1.88 \pm 0.45$ & $1.85 \pm 0.49$ & $-0.03 \mathrm{NS}$ \\
Galium album & & & \\
Richness & $16.49 \pm 5.90$ & $16.40 \pm 6.28$ & $-0.09 \mathrm{NS}$ \\
Diversity & $1.87 \pm 0.44$ & $1.85 \pm 0.49$ & $-0.02 \mathrm{NS}$ \\
Trifolium hybridum & & & \\
Richness & $16.93 \pm 5.86$ & $16.31 \pm 6.26$ & $-0.62 \mathrm{NS}$ \\
Diversity & $1.87 \pm 0.46$ & $1.85 \pm 0.49$ & $-0.02 \mathrm{NS}$ \\
\hline
\end{tabular}

\section{Environmental factors affecting the occurrence of neophyte species}

For the 2001 data, PCA of the environmental variables produced two axes, for the 2005 data four axes, and for the 2010 data three axes, explaining $51.8 \%, 75.2 \%$ and $60.5 \%$ of the variation, respectively (Table 5). In 2001 and 2005, the first axes were dominated by native and alien species richness and longitude; and the second axes by latitude and shadiness. In 2005, the third axis represented the proportion of bare ground, and the fourth moisture of the habitats. In 2010, the first axis was dominated by native species richness, longitude and shadiness; the second by moisture, proportion of bare ground and alien species richness, and the third by latitude.

In 2001 and 2005, all the four studied species were positively related to PCA axes, which represented the native and alien species richness and longitude, and the occurrence of the species seemed to increase with native and alien species richness and in an eastern direction (Tables 6 and 7). In 2010, only A. ptarmica was positively associated with longitude, native species richness and shadiness. All studied neophyte species were associated with the PCA axis dominated by latitude and alien species richness in 2010. For $A$. ptarmica the relationship was positive and the occurrence of $A$. ptarmica seemed to increase with latitude and decrease with alien species richness, whereas for other species the relationship was negative, and their occurrence seemed to decrease northwards and increase with alien species richness (Table 6). G. album and T. hybridum were also negatively associated with latitude in 2001 (Tables 6 and 7). A. ptarmica, G. album and $T$. hybridum were more strongly associated with habitat type than E. adenocaulon. E. adenocaulon was positively related to the proportion of bare ground and moisture in 2005 and 2010. In addition, the occurrence of T. hybridum seemed to decrease with increasing moisture in 2005 and 2010, and increase with the proportion of bare ground and alien species richness in 2010 (Table 7). A. ptarmica (in 2005) and G. album (in 2010) were positively related to mowing. Habitat type was a significant factor for $A$. ptarmica 


\section{AGRICULTURAL AND FOOD SCIENCE}

M. Jauni et al. (2012) 21: 100-117

in 2001 and 2010, for G. album in 2005, and for T. hybridum in 2001 and 2005, whereas E. adenocaulon was not strongly related to the habitat type based on the results of the generalized linear mixed models.

Table 5. Eigenvalues and the proportion of explained variation for composite variables of environmental conditions based on principal components analysis in semi-natural agricultural habitats in 2001, 2005 and 2010. Factor loadings of the original variable greater than 0.5 are marked in bold.

\begin{tabular}{|c|c|c|c|c|}
\hline & PCA1 & PCA2 & PCA3 & PCA4 \\
\hline \multicolumn{5}{|l|}{2001} \\
\hline Moisture & -0.300 & 0.492 & & \\
\hline Shadiness $^{1}$ & -0.018 & 0.618 & & \\
\hline Bare ground ${ }^{1}$ & 0.149 & 0.425 & & \\
\hline Native species ${ }^{1}$ & 0.867 & 0.012 & & \\
\hline Alien species ${ }^{1}$ & 0.755 & -0.357 & & \\
\hline Longitude $^{1}$ & 0.782 & 0.218 & & \\
\hline Latitude & -0.045 & 0.772 & & \\
\hline Eigenvalue & 2.135 & 1.491 & & \\
\hline Variation explained \% & 30.5 & 21.3 & & \\
\hline \multicolumn{5}{|l|}{2005} \\
\hline Moisture & -0.073 & 0.032 & -0.054 & 0.887 \\
\hline Shadiness $^{1}$ & 0.111 & 0.854 & 0.036 & 0.158 \\
\hline Bare ground ${ }^{1}$ & 0.037 & -0.057 & 0.943 & -0.030 \\
\hline Native species & 0.839 & 0.170 & 0.044 & 0.145 \\
\hline Alien species & 0.730 & -0.049 & 0.276 & -0.230 \\
\hline Longitude $^{1}$ & 0.729 & -0.204 & -0.387 & -0.023 \\
\hline Latitude & 0.214 & -0.630 & 0.163 & 0.437 \\
\hline Eigenvalue & 1.847 & 1.232 & 1.168 & 1.012 \\
\hline Variation explained \% & 26.4 & 17.6 & 16.7 & 14.5 \\
\hline \multicolumn{5}{|l|}{2010} \\
\hline Moisture & 0.159 & -0.721 & -0.229 & \\
\hline Shadiness & 0.653 & -0.138 & 0.112 & \\
\hline Bare ground ${ }^{1}$ & -0.031 & 0.717 & -0.172 & \\
\hline Native species & 0.828 & -0.013 & -0.196 & \\
\hline Alien species & 0.329 & 0.557 & -0.560 & \\
\hline Longitude $^{1}$ & 0.562 & 0.051 & 0.327 & \\
\hline Latitude & 0.186 & 0.026 & 0.848 & \\
\hline Eigenvalue & 1.626 & 1.540 & 1.071 & \\
\hline Variation explained \% & 23.2 & 22.0 & 15.3 & \\
\hline
\end{tabular}

${ }^{1}$ Log-transformed 


\section{AGRICULTURAL AND FOOD SCIENCE}

M. Jauni et al. (2012) 21: 100-117

Table 6. The results of generalized linear mixed models analysis (GLMM) of the effects of environmental variables on Achillea ptarmica and Epilobium adenocaulon in semi-natural agricultural habitats in 2001, 2005 and 2010 using backward deletion. Parameter estimates, z-values and p-values are shown.

\begin{tabular}{|c|c|c|c|c|c|c|}
\hline & \multicolumn{3}{|c|}{ Achillea ptarmica } & \multicolumn{3}{|c|}{ Epilobium adenocaulon } \\
\hline & Estimate & $\mathrm{z}$ & $p$ & Estimate & $\mathrm{z}$ & $p$ \\
\hline \multicolumn{7}{|l|}{2001} \\
\hline Intercept & 0.17 & & & -2.38 & & \\
\hline Habitat: Forest margin & -0.36 & -1.25 & 0.211 & & & \\
\hline Habitat: Road margin & 0.29 & 0.97 & 0.334 & & & \\
\hline Habitat: Grassland & -0.69 & -2.00 & 0.046 & & & \\
\hline Habitat: Others & -0.17 & -0.37 & 0.708 & & & \\
\hline PCA1 & 0.89 & 5.85 & $<0.001$ & 0.91 & 4.52 & $<0.001$ \\
\hline \multicolumn{7}{|l|}{ PCA2 } \\
\hline \multicolumn{7}{|l|}{2005} \\
\hline Intercept & -0.55 & & & -1.88 & & \\
\hline \multicolumn{7}{|l|}{ Habitat: Forest margin } \\
\hline \multicolumn{7}{|l|}{ Habitat: Road margin } \\
\hline \multicolumn{7}{|l|}{ Habitat: Grassland } \\
\hline \multicolumn{7}{|l|}{ Habitat: Others } \\
\hline Mow & 1.04 & 3.09 & 0.002 & & & \\
\hline PCA1 & 1.28 & 7.93 & $<0.001$ & 0.55 & 4.01 & $<0.001$ \\
\hline PCA3 & & & & 0.54 & 4.13 & $<0.001$ \\
\hline PCA4 & & & & 0.42 & 3.30 & $<0.001$ \\
\hline \multicolumn{7}{|l|}{2010} \\
\hline Intercept & -0.15 & & & -1.69 & & \\
\hline Habitat: Forest margin & -0.39 & -1.20 & 0.229 & & & \\
\hline Habitat: Road margin & 0.44 & 1.51 & 0.131 & & & \\
\hline Habitat: Grassland & -1.13 & -2.94 & 0.003 & & & \\
\hline Habitat: Others & -0.39 & -0.89 & 0.372 & & & \\
\hline \multicolumn{7}{|l|}{ Mow } \\
\hline PCA1 & 0.64 & 4.42 & $<0.001$ & & & \\
\hline PCA2 & & & & 0.24 & 1.99 & 0.047 \\
\hline PCA3 & 0.34 & 2.44 & 0.015 & -0.81 & -4.79 & $<0.001$ \\
\hline
\end{tabular}




\section{AGRICULTURAL AND FOOD SCIENCE}

M. Jauni et al. (2012) 21: 100-117

Table 7. The results of generalized linear mixed models analysis (GLMM) of the effects of environmental variables on Galium album and Trifolium hybridum in semi-natural agricultural habitats in 2001, 2005 and 2010 using backward deletion. Parameter estimates, z-values and $p$-values are shown.

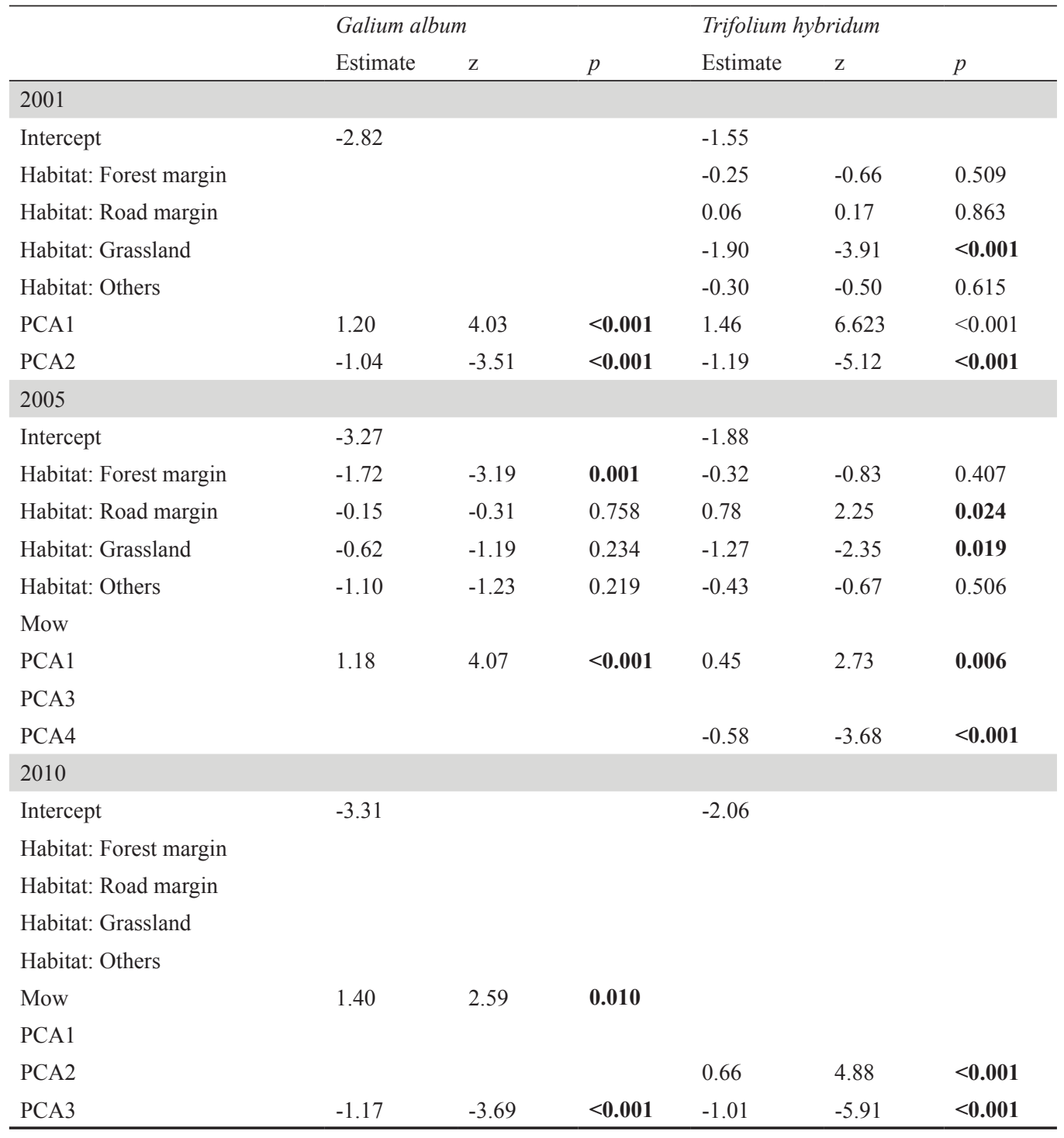




\section{AGRICULTURAL AND FOOD SCIENCE}

M. Jauni et al. (2012) 21: 100-117

\section{Discussion}

We observed strong spatio-temporal variation in invasion level, which was enhanced by environmental, geographic and climatic variation and depended on the measure used for invasion level (see Jauni and Hyvönen 2010). When invasion level of an alien plant (including archaeophytes and neophytes) was measured as relative alien species richness, no temporal variation was detected across the country. When invasion level was measured as alien species diversity, temporal variation indicated lower alien species diversity in 2005 than in other study years, which may be induced by geographical differences and climate. For instance, in 2005 , the summer precipitation was higher than average for the other study years, and the growing season began later than average (Kuussaari et al. 2008). In addition, variation in disturbance regime and fluctuation in resource availability, such as nutrients, water and light can contribute to spatio-temporal variation in the occurrence and spread of alien plant species (see e.g. Davis et al. 2000, Richardson and Pyšek 2006). Higher alien species diversity may indicate that alien species are present in high numbers and no dominant species occur (see e.g. Catford et al. 2012). Thus, variation in environmental conditions, especially climate, may not change relative alien species richness, but may increase the relative abundance of more dominant alien species.

We found that the invasion level varied according to the geographical location, for instance the relative alien species richness was lower in eastern and western Finland than in southern and south-western Finland. This may result from the invasion history, landscape structure, land-use history and climate (e.g. Luoto 2000, Kivinen et al. 2006, Jauni and Hyvönen 2010). Generally, there was a trend of increasing occurrence of common neophytes towards the east and a decrease northwards (see Jauni and Hyvönen 2010). Similar geographic trends have been detected for other plant species, butterflies and bees, and such trends may be explained partially by the more continental climate towards east and species dispersal through landconnected eastern migration routes, and by decreasing mean daily temperatures and shortening growing season towards north in Finland (e.g. Kivinen et al. 2006).

We studied alien plant species (i.e. neophytes) in semi-natural agricultural habitats over a decade. This temporal scale gave an opportunity to detect alien species new to the areas, and to observe temporal variation in the occurrence and frequency of aliens already present. Ten new alien species, including highly invasive Symphytum officinale and Calystegia sepium, were detected for the first time in our transect lines in 2010. Generally, most of the highly invasive alien species were rare and occurred occasionally in the semi-natural agricultural habitats. For the time being, several plant species that are considered highly invasive in Finland, such as Heracleum mantegazzianum Sommier \& Levier, Solidago canadensis L., Rosa rugosa Thunb. Ex Murray, Impatiens glandulifera Royle, and Avena fatua L. (MMM 2012), are not detected in the semi-natural agricultural habitats. Thus, our results suggest that invasive alien plant species are not widely established in boreal semi-natural agricultural habitats in Finland.

The finding that invasive species were mainly rare in semi-natural agricultural habitats is surprising since most of the studied invasive alien species favour agricultural and/or ruderal habitats. They arrived in Finland over 100 years ago and they are already established (e.g. Hämet-Ahti et al. 1998, Hyvönen and Jalli 2011). Usually, the longer the alien species are present in an area, the higher is their chance of becoming established and spread into new areas (Pyšek and Jarošik, 2005). It usually takes at least 150 years for naturalized alien species to fill their maximum range (e.g. Williamson et al. 2009). For instance, E. adenocaulon invaded Finland, with the exception of Lapland, during the last 100 years (Lampinen and Lahti 2011). The current distribution may be due to the harsh climate in Finland, which may hinder further distribution and increase in the abundance. Most of the invasive alien species do not occur in northern 


\section{AGRICULTURAL AND FOOD SCIENCE}

M. Jauni et al. (2012) 21: 100-117

Finland, and highly invasive species, such as Sambucus racemosa, C. sepium and S. officinale, are rare not only in semi-natural agricultural habitats but throughout Finland (Lampinen and Lahti 2011). In addition, the Finnish agricultural landscape is a mosaic of arable land and forest (e.g. Luoto 2000), and the proximity of forest may not represent an advantage for the survival of alien plant species (Jauni and Hyvönen 2010). Furthermore, interactions between invading and resident species, for instance competition for available resources, may hinder the invasion and establishment of new plant species in agricultural habitats (Davis et al. 2000, Levine et al. 2003, Richardson and Pyšek 2006). The abundance of most of the studied alien species was low, thus they are not able to effectively compete against resident species and invade new areas.

We found some evidence of lag times in the spread of alien plant species, and that not all alien plants respond similarly to geographic location. For instance, occurrence of $A$. ptarmica was more strongly related to longitude than occurrences of the other common neophyte species. In addition the frequencies of occurrence of Lolium perenne L. and T. hybridum decreased after 2001, and have remained relatively stable. The lag time, when species occurrence is rather stable, may be caused by the lack of suitable habitats or inclement environmental conditions (Crooks 2005, Pyšek and Hulme 2005). For instance, in Austria a lag phase of Ambrosia artemisiifolia L. continued almost 70 years after the first records of casual populations, until the onset of the exponential increase due to niche expansion (Essl et al. 2009). In relation to underlying processes, 10 years is a short monitoring period for alien plant distributions, even if marked changes in the spread of highly invasive alien species, such as I. glandulifera and H. mantegazzianum, may occur over short time periods (see e.g. Pyšek and Prach 1993). Currently there is no evidence of such quick invasions of alien plant species in agricultural habitats in Finland. Our temporal scale consisted of three separate years, thus the changes in species occurrence may also reflect stochastic variation in environmental conditions. To overcome this problem, a longer period of monitoring and more frequent monitoring would be needed.

The most common alien species responded differently to the disturbance regime. A. ptarmica and G. album were more strongly and positively related to mowing, whereas $E$. adenocaulon and T. hybridum were more strongly associated with the proportion of bare ground. The effects of different types of disturbances can vary within the habitat type and among plant species, thus alien species cannot be viewed as a single group of species with similar responses to the same level of disturbance (Hobbs and Huenneke 1992). As species vary in their response to disturbance regime, this should be taken into account when making management choices (e.g. Hobbs and Huenneke 1992). In addition, the four most common alien species varied in their preferences for habitat type in an agricultural landscape. A. ptarmica and T. hybridum in particular were associated with road margins, whereas $E$. adenocaulon seemed to be more habitat generalist. Thus, our results suggest that preferences for environmental conditions are not equal for all alien plants, and this should be taken into account when planning management and control methods.

In contrast to previous studies on the effects of alien species on species diversity (e.g. Valtonen et al. 2006, Hejda et al. 2009, Pyšek et al. 2009, Vilá et al. 2011), we found that most common alien species were positively rather than negatively related to native species richness and diversity. This may be caused for instance by the lack of competition and availability of suitable niches for both alien and native plant species (e.g. Stohlgren et al. 2006). Not even the occurrence of the most common invasive alien species ( $E$. adenocaulon and G. album) decreased the plant diversity in semi-natural agricultural habitats. However, these results do not demonstrate that such invasive alien species are harmless for plant diversity because their effects may not be directed to the whole plant community. For instance, G. album is known to have a negative effect only on the native congener G. verum (e.g. Nummi 2001, MMM 2012). G. album can hybridize with $G$. verum, leading to genetic merging of $G$. verum into $G$. album and the eventual loss of 


\title{
AGRICULTURAL AND FOOD SCIENCE
}

\author{
M. Jauni et al. (2012) 21: 100-117
}

G. verum (e.g. Nummi 2001). In addition, A. ptarmica, more than other studied species, affected more strongly and positively native species richness and diversity throughout the decade. Thus, impacts of alien species on native species, communities and ecosystems are heterogeneous and species-specific, and the severity of the impact depends on the identity of the invading species (Hejda et al. 2009, Vilà et al. 2011). Management strategies should therefore be considered on a case-by-case basis, taking into account the local conditions.

Agricultural habitats are among the most invaded habitats in Europe and in Finland (e.g. Pyšek et al. 2009, Jauni and Hyvönen 2010). However, it generally appears that alien plant species do not currently cause severe problems in semi-natural agricultural habitats in Finland, and the most harmful invasive alien plants, such as Heracleum mantegazzianum, have not yet invaded these habitats. For instance, Lupinus polyphyllus, which is known to change the structure of plant communities, and decrease plant species richness in roadside verges in Finland (Valtonen et al. 2006), is not common in semi-natural agricultural habitats in Finland. However, the situation may not remain the same, and due non-linearity of the plant invasion, regular monitoring is needed in order to detect changes in the distribution and spread of alien species and to direct the control and management methods efficiently.

\section{Acknowledgements}

We thank anonymous reviewers for their comments and Jonathan Robinson for the language revision. We acknowledge funding from the Jenny and Antti Wihuri Foundation (M.J.), Niemi Foundation (M.J.), the Academy of Finland (T.H.; the project number 122477), and MTT Agrifood Research Finland.

\section{References}

Bates, D., Maechler, M. \& Bolker, B. 2011. Ime4: Linear mixed-effects models using S4 classes. http://CRAN.R-project. org/package=Ime4. Cited 17 April 2012.

Catford, J.A., Vesk, P.A., Richardson, D.M. \& Pyšek, P. 2011. Quantifying levels of biological invasion: towards the objective classification of invaded and invasible ecosystems. Global Change Biology 18:44-62.

Chytrý, M., Jarošik, V., Pyšek, P., Hájek, O., Knollová, I., Tichý, L. \& Danihelka, J. 2008. Separating habitat invasibility by alien plants from the actual level of invasion. Ecology 89: 1541-1553.

Chytrý, M., Pyšek, P., Wild, J., Pino, J., Maskell, L.C. \& Vilà, M. 2009. European map of alien plant invasions based on the quantitative assessment across habitats. Diversity and Distributions 15: 98-107.

Crooks, J.A. 2005. Lag times and exotic species: the ecology and management of biological invasions in slow-motion. Ecoscience 12: 316-329.

Davis, M.A., Grime, P. \& Thompson, K. 2000. Fluctuating resources in plant communities: a general theory of invasibility. Journal of Ecology 88:528-534.

Essl, F., Dullinger, S. \& Kleinbauer, I. 2009. Changes in the spatio-temporal patterns and habitat preferences of Ambrosia artemisiifolia during its invasion of Austria. Preslia 81: 119-133.

Hejda, M., Pyšek, P. \& Jarošik, V. 2009. Impact of invasive plants on the species richness, diversity and composition of invaded communities. Journal of Ecology 97: 393-403.

Hobbs, R.J. \& Huenneke, L.F. 1992. Disturbance, diversity, and invasion. Implications for conservation. Conservation Biology 6: 324-337.

Holm, S. 1979. A simple sequentially rejective multiple test procedure. Scandinavian Journal of Statistics 6: 65-70.

Hyvönen, T. \& Jalli, H. 2011. Alien species in the Finnish weed flora. Agricultural and Food Science 20:86-95.

Hämet-Ahti, L., Suominen, J., Ulvinen, T. \& Uotila, P. (eds.) 1998. Retkeilykasvio (Field Flora of Finland). Fourth ed. 


\title{
AGRICULTURAL AND FOOD SCIENCE
}

\author{
M. Jauni et al. (2012) 21: 100-117
}

Helsinki: Finnish Museum of Natural History, Botanical Museum. 656 p.

Jauni, M. \& Hyvönen, T. 2010. Invasion level of alien plants in semi-natural agricultural habitats in boreal region. Agriculture, Ecosystems and Environment 138: 109-115.

Kent, M. \& Coker, P. 1992. Vegetation Description and Analysis, a Practical Approach. London: Belhaven Press. 384 p.

Kivinen, S., Luoto, M., Kuussaari, M. \& Helenius, J. 2006. Multi-species richness of boreal agricultural landscapes: effects of climate, biotope, soil and geographic location. Journal of Biogeography 33: 862-875.

Kuussaari, M., Heliölä, J., Tiainen, J. \& Helenius, J. (eds.) 2008. Significance of the Finnish Agri-environment Scheme for Biodiversity and Landscape: Final Report 2000-2006. Finnish Environment 4: 1-208.

Kuussaari, M., Heliölä, J. \& Luoto, M. 2004. Farmland biodiversity indicators and monitoring in Finland. In: Groom, G. (ed.). Developments in Strategic Landscape Monitoring for the Nordic Countries. Nordic Council of ministers, Copenhagen. p. 29-40.

Lampinen, R. \& Lahti, T. 2011. Kasviatlas 2010. Helsingin Yliopisto, Luonnontieteellinen keskusmuseo, Kasvimuseo, Helsinki. Available on the Internet: http://www.luomus.fi/kasviatlas.

Levine, J.M., Vilà, M., D’Antonio, C.M., Dukes, J.S., Grigulis, K. \& Lavorel, S. 2003. Mechanisms underlying the impacts of exotic plant invasions. Proceedings of the Royal Society London B 270: 775-781.

Lonsdale, W.M. 1999. Global patterns of plant invasions ant the concept of invasibility. Ecology 80: 1522-1536.

Luoto, M. 2000. Spatial analysis of landscape ecological characteristics of five agricultural areas in Finland by GIS. Fennia 178: 15-54.

MMM. 2012. Finland's National Strategy on Invasive Alien Species. Johanna Niemivuo-Lahti (ed.). Based on the proposal prepared by the working group on a National Strategy on Invasive Alien Species. Ministry of Agriculture and Forestry. 126 p.

NOBANIS. 2011. North European and Baltic network on invasive species. Available on the Internet: http://www. nobanis.org.

Nummi, P. 2001. Alien species in Finland. The Finnish Environment 466. Ministry of the Environment.

Pyšek, P. \& Prach, K. 1993. Plant invasions and the role of riparian habitats: a comparison of four species alien to Central Europe. Journal of Biogeography 20: 413-420.

Pyšek, P. \& Hulme, P.E. 2005. Spatio-temporal dynamics of plant invasion: linking pattern to process. Ecoscience 12 : 302-315.

Pyšek, P. \& Jarošik, V. 2005. Residence time determines the distribution of alien plants. In: Inderjit (ed.). Invasive Plants: Ecological and Agricultural Aspects. Basel, Switzerland: Birkhäuser Verlag. p. 77-96.

Pyšek, P., Lambdon, P.W., Arianoutsou, M., Kühn, I., Pino, J. \&Winter, M. 2009. Alien vascular plants of Europe. In: DAISIE, (ed.) Handbook of Alien Species in Europe.Dordrech: Springer Science+Business Media B.V. p. 43-61.

R Development Core Team. 2011. R: A language and environment for statistical computing. R Foundation for Statistical Computing, Vienna, Austria. ISBN 3-900051-07-0, URL http://www.R-project.org/. Cited 17.4.2012.

Ranta, P. \& Viljanen, V. 2011. Vascular plants along an urban-rural gradient in the city of Tampere, Finland. Urban Ecosystems 14: 361-376.

Rejmánek, M., Richardson, D.M. \& Pyšek, P. 2005. Plant invasions and invasibility of plant communities. In: van der Maarel, E. (ed.) Vegetation Ecology. Oxford: Blackwell Science, p. 332-355.

Richardson, D.M., Pyšek, P., Rejmánek, M., Barbour, M.G., Panetta, F.D. \& West, C.J. 2000. Naturalization and invasion of alien plants concepts and definitions. Diversity and Distributions 6: 93-107.

Richardson, D.M. \& Pyšek, P. 2006. Plant invasions: merging the concepts of species invasiveness and community invasibility. Progress in Physical Geography 30: 409-431.

Simberloff, D. 2011. How common are invasion-induced ecosystem impacts. Biological Invasions 13: 1255-1268.

SPSS Inc. 2009. PASW STATISTICS 17.0 Command Syntax Reference. SPSS Inc., Chicago.

Stohlgren, T.J., Binkley, D., Chong, G.W., Kalkhan, M.A., Schell, L.D., Bull, K.A., Otsuki, Y., Newman, G., Bashkin, M. \& Son, Y. 1999. Exotic plant species invade hot spots of native plant diversity. Ecological Monographs 69: 25-46.

Stohlgren, T.J., Jarnevich, C., Chong, G.W. \& Evangelista, P.H. 2006. Scale and plant invasions: a theory of biotic ac- 


\section{AGRICULTURAL AND FOOD SCIENCE}

M. Jauni et al. (2012) 21: 100-117

ceptance. Preslia 78: 405-426.

Suominen, J. \& Hämet-Ahti, L. 1993. Archaeophytes in the flora of Finland. Norrlinia 4: 1-90.

Valtonen, A., Jantunen, J. \& Saarinen, K. 2006. Flora and lepidoptera fauna adversely affected by invasive Lupinus poluphyllus along road verges. Biological Conservation 133: 389-396.

Vilà, M., Espinar, J., Hejda, M., Hulme, P.E., Jaroŝík, V., Maron, J.L., Pergl, J., Schaffner, U., Sun, Y. \& Pyŝek, P. 2011. Ecological impacts of invasive alien plants: a meta-analysis of their effect on species, communities and ecosystems. Ecology Letters 14: 702-708.

Williamson, M., Dehnen-Schmutz, K., Kühn, I., Hill, M., Klotz, S., Milbau, A., Stout, J. \& Pyšek, P. 2009. Distribution of range sizes of native and alien plants in four European countries and the effects of residence time. Diversity and Distributions 15: 158-166. 


\section{AGRICULTURAL AND FOOD SCIENCE}

M. Jauni et al. (2012) 21: 100-117

Appendix 1. Percentage distribution over habitat types of the $50 \mathrm{~m}^{2}$ transects $(\mathrm{N}=508)$ either invaded or uninvaded by the neophyte species in 2001, 2005, and 2010. Significant p-values based on Pearson's chi square test (indicating difference in the distribution over the habitat types between invaded and uninvaded transects) are bolded.

\begin{tabular}{|c|c|c|c|c|c|c|}
\hline & \multicolumn{2}{|l|}{2001} & \multicolumn{2}{|l|}{2005} & \multicolumn{2}{|c|}{2010} \\
\hline & $\begin{array}{r}\text { Invaded } \\
(\%)\end{array}$ & $\begin{array}{r}\text { Uninvaded } \\
(\%)\end{array}$ & $\begin{array}{r}\text { Invaded } \\
(\%)\end{array}$ & $\begin{array}{r}\text { Uninvaded } \\
(\%)\end{array}$ & $\begin{array}{r}\text { Invaded } \\
(\%)\end{array}$ & $\begin{array}{r}\text { Uninvaded } \\
(\%)\end{array}$ \\
\hline \multicolumn{7}{|c|}{ Achillea ptarmica } \\
\hline Field margin & 32.9 & 35.5 & 31.2 & 36.6 & 30.0 & 40.4 \\
\hline Forest margin & 23.4 & 23.4 & 28.0 & 20.3 & 25.9 & 22.0 \\
\hline Road margin & 25.4 & 15.2 & 23.9 & 16.6 & 22.8 & 16.3 \\
\hline Grassland & 11.5 & 18.4 & 9.2 & 19.3 & 15.2 & 12.2 \\
\hline Other & 6.7 & 7.4 & 7.8 & 7.2 & 6.1 & 9.0 \\
\hline Estimate & 10.79 & & 16.08 & & 19.60 & \\
\hline$p$-value & 0.058 & & 0.009 & & 0.048 & \\
\hline \multicolumn{7}{|c|}{ Epilobium adenocaulon } \\
\hline Field margin & 34.7 & 34.2 & 34.5 & 34.2 & 37.5 & 33.2 \\
\hline Forest margin & 26.7 & 22.9 & 33.3 & 21.6 & 25.7 & 23.7 \\
\hline Road margin & 20.0 & 20.3 & 16.1 & 20.4 & 21.1 & 20.7 \\
\hline Grassland & 14.7 & 15.0 & 8.0 & 16.4 & 14.7 & 14.2 \\
\hline Other & 4.0 & 7.6 & 8.0 & 7.7 & 8.0 & 8.2 \\
\hline Estimate & 1.59 & & 8.28 & & 4.67 & \\
\hline$p$-value & 0.811 & & 0.246 & & 0.646 & \\
\hline \multicolumn{7}{|l|}{ Galium album } \\
\hline Field margin & 33.6 & 34.4 & 37.1 & 33.6 & 35.3 & 34.9 \\
\hline Forest margin & 18.5 & 24.9 & 15.5 & 25.5 & 19.0 & 25.5 \\
\hline Road margin & 26.1 & 18.5 & 26.8 & 18.0 & 26.7 & 17.6 \\
\hline Grassland & 17.6 & 14.1 & 16.5 & 14.6 & 13.8 & 13.8 \\
\hline Other & 4.2 & 8.0 & 4.1 & 8.3 & 5.2 & 8.2 \\
\hline Estimate & 6.77 & & 8.75 & & 6.46 & \\
\hline$p$-value & 0.298 & & 0.204 & & 0.168 & \\
\hline \multicolumn{7}{|c|}{ Trifolium hybridum } \\
\hline Field margin & 34.4 & 34.2 & 29.9 & 35.2 & 28.4 & 36.4 \\
\hline Forest margin & 19.8 & 24.7 & 20.7 & 24.2 & 25.0 & 23.8 \\
\hline Road margin & 29.0 & 17.2 & 37.9 & 15.9 & 31.8 & 17.1 \\
\hline Grassland & 11.5 & 16.2 & 6.9 & 16.6 & 10.2 & 14.5 \\
\hline Other & 5.3 & 7.7 & 4.6 & 8.1 & 4.5 & 8.1 \\
\hline Estimate & 9.81 & & 24.45 & & 11.54 & \\
\hline$p$-value & 0.044 & & $<0.001$ & & 0.042 & \\
\hline
\end{tabular}

